\title{
FORMAREA ŞI EDUCAŢIA MORALĂ ÎN CADRUL FAMILIEI: AUTOEDUCAȚIA MORALĂ ŞI PERFECŢIONAREA SPIRITUALĂ
}

Larisa Cuzneţov*

\begin{abstract}
This article represents a theoretical study with practical implications, which elucidates the formation and moral education in the family. Focus is placed on the formation of conscience and moral conduct; the realization of Strategic model perspective and on Instrumental education morality model. The study also reflects 7-steps regularities focused on spiritual training and on parent self-training strategy, which have been successfully implemented in the practice of family education (in several high schools in mun. Chisinau; 620 families experimental group).
\end{abstract}

Keywords: moral education in the family, moral conduct, moral conscience.

Esenţa şi caracteristica definitorie a omului şi a umanităţii o constituie moralitatea, conştiinţa, acţiunea şi conduita morală. Formarea morală a fiinţei umane reprezintă una dintre sarcinile primordiale ale educaţiei dintotdeauna. Educaţia morală reprezintă dimensiunea cea mai profundă şi mai extinsă a activităţii de formaredezvoltare a personalităţii, proiectată şi realizată în baza moralei şi a valorilor etice $[2 ; 3 ; 5]$. Impactul şi resursele acestei dimensiuni sunt apreciate de unii cercetători ca educaţia însăşi [13, p. 401], care gravitează în jurul valorificării binelui moral, asumat şi exteriorizat în plan individual şi social prin comportamentul persoanei ce denotă unitatea, coerenţa şi interconexiunea conştiinţei şi conduitei morale. Definirea conceptului de educaţie morală presupune raportarea dimensiunii vizate la noţiunea de morală, care va fi analizată din perspectiva filosofiei, psihologiei sociale şi pedagogiei.

Astfel, din perspectivă filosofică, morală desemnează o teorie a relaţiilor omului cu lumea şi cu sine, care evidenţiază rolul activ al conştiinţei umane în formarea-dezvoltarea personalităţii

**PhD, dr. hab., Professor, State Pedagogical University „Ion Creangă”. 
[Apud 8, p. 145]. Dicţionarul de filosofie Larousse oferă o definiţie concisă şi explicită: morala este ştiinţa binelui şi a regulilor acţiunii umane. După cum am menţionat anterior, din optica filosofiei practice, care reprezintă o parte a filosofiei, consacrată problemei acţiunii umane, morala include reflecţia şi acţiunea umană axate pe dobândirea fericirii.

Din perspectiva psihologiei sociale, morala reprezintă o formă a conştiinţei sociale, care reflectă existenţa socială la nivel teoretic/conceptual, ideologic, normativ şi practic, adică acţional şi comportamental [9, p. 21-22].

Perspectiva pedagogică ne orientează spre cultivarea morală a persoanei. Ea conturează finalităţile, traseul, conţinutul şi metodologia formării-dezvoltării conştiinţei şi conduitei morale a personalităţii în unitatea şi interconexiunea manifestării acestora $[5 ; 6 ; 7 ; 14 ; 15]$.

Aşadar, formarea conştiinţei morale include componenta teoretică ce presupune familiarizarea subiectului cu ansamblul de concepte, norme, judecăţi, raţionamente morale, idei, concepţii, inclusiv sentimente şi atitudini morale, care vor contribui, substanţial, la formarea convingerilor, aspiraţiilor, idealului moral şi comportamentului personalităţii.

Articularea şi consolidarea acestora în cadrul vieţii şi a educaţiei familiale se va realiza prin interiorizarea şi respectarea normelor şi valorilor morale, adoptate şi valorificate la maximum, permanent de către toţi membrii acesteia, adulţi şi copii.

Formarea conduitei morale în cadrul familiei se desfăşoară concomitent cu formarea conştiinţei, adulţii urmărind ca asimilarea unei norme să fie corelată cu acţiuni şi fapte concrete, exersate şi repetate continuu pentru a forma deprinderi şi obişnuinţe morale, care se vor structura treptat în voinţa morală şi caracterul integru, valoros din punct de vedere axiologic.

Întrucât obiectivele educaţiei morale se situează pe cele două axe, formarea conştiinţei morale şi formarea conduitei morale, obiectivele specifice acestora, proiectate, urmate şi realizate în procesul educaţiei familiale vizează: 


\section{La nivelul formării conştiinței morale:}

- formarea-dezvoltarea capacităţilor cognitive morale (percepţii, reprezentări, noţiuni, judecăţi, raţionamente morale);

- formarea-dezvoltarea capacităţilor afective, motivaţionale, volitive, morale (sentimente, interese, competenţe, trăsături moral-volitive);

- formarea-dezvoltarea convingerilor morale, a capacităţilor reflexive şi de interiorizare conştientă a normelor morale (care asigură analiza şi sinteza în plan filosofic, dar şi psiho-social, marcând trecerea de la nivelul teoretic la nivelul acţional-practic al conştiinţei morale.

\section{La nivelul formării cond uitei morale:}

- formarea-dezvoltarea priceperilor şi deprinderilor morale (componente ale competenţelor ce au fost consolidate până la nivelul automatismelor/acţiuni morale automatizate);

- formarea-dezvoltarea obişnuinţelor morale, ca componente automatizate, perfecţionate prin intensificarea motivelor interne ale acţiunii ce au impact stabilizator;

- formarea-dezvoltarea atitudinilor şi a trăsăturilor moral-volitive de caracter, ceea ce determină consecvenţa şi coerenţa acţiunii şi conduitei morale [Apud 8, p. 147].

Evident că managerii şcolari, psihologii, care conduc şedinţele, atelierele din cadrul şcolilor pentru părinţi (ce funcţionează în marea majoritate a instituţiile de învăţământ din Republica Moldova) sunt, pur şi simplu, obligaţi, să iniţieze familia/părinţii în domeniul educaţiei morale a copiilor, începând cu acordarea ajutorului în proiectarea obiectivelor şi a conţinutului educaţiei familiale, a activităţilor, utilizării metodelor şi formelor de realizare a acestora, pentru a spori competenţa adulţilor şi a corela educaţia morală familială cu cea şcolară.

În formarea părinţilor şi copiilor este necesar de centrat pe respectarea particularităţilor de vârstă, a drepturilor omului/copilului; pe familiarizarea ambelor părţi cu specificul educaţiei morale şi structurile personalităţii umane, inclusiv cu nivelurile şi posibilităţile 
ratificării valorice a conduitelor morale. În acest aspect poate şi trebuie să fie realizată permanent/pe parcursul vieţii educaţia religioasă şi cultivarea spiritualităţii prin valorificarea parteneriatelor sociale familie - şcoală - biserică - comunitate şi desigur că a modelelor parentale pozitive în ceea ce priveşte relaţia sa cu Dumnezeu, cu sine, cu apropiaţii săi, Natura şi Lumea.

Atât în practica familiei, cât şi în cea şcolară şi cea comunitară, este necesar de observat şi validat, dezaprobat, sancţionat sau, invers, de încurajat şi consolidat conduitele dezirabile şi/sau indezirabile ale copiilor, elevilor, adulţilor.

Experienţa avansată privind educaţia morală şi analiza vieţii, relaţiilor familiale, demonstrează eficienţa a patru niveluri ce ţin de discursul valorizator în plan etic, definite şi descrise de $M$. Aiken [Apud 8, p. 148-149], pe care noi le-am dezvoltat şi completat:

a) nivelul expresiv-evocativ. Constă în utilizarea mimicii şi a gesturilor în locul verbalizării unor expresii evaluative pentru a aprecia sau dezaproba unele acţiuni sau comportamente ale copiilor în situaţii concrete. Adulţii, în cadrul familiei, aplică frecvent acest mod de evaluare, transmiţând anumite sentimente pentru redarea empatizării, încurajarea sau dezaprobarea unor fapte, comportamente ale copiilor. Important este să nu facem abuz în valorificarea nivelului dat;

b) nivelul moral. Este unul foarte important, deoarece presupune valorizarea a două aspectele ale educaţiei morale, primul axându-se pe cerinţele morale, iar cel de-al doilea - pe respectarea regulilor şi standardelor morale. În acest sens, trebuie ca părinţii să cunoască ansamblul de cerinţe şi reguli/standarde morale, să le respecte, la fel, să fie în stare a formula cerinţe, constatări şi evaluări în baza acestora în conformitate cu vârsta copilului. Este important să înţelegem că nivelul evaluativ în formarea morală a copilului, constituie miezul logicii şi al strategiei fundamentale a familiei aplicate în educaţia morala a tinerei generaţii. Nivelul dat necesită o completare cu educaţia şi formarea unui creştin adevărat;

c) nivelul etic/al evaluării normative. Dacă la nivelul precedent, regulile şi standardele morale puteau să nu se analizeze, să nu se discute cu copiii, deoarece aceştia erau prea mici, atunci la acest nivel, copiii 
încep a înţelege esenţa normelor şi valorilor morale şi sunt capabili să le analizeze şi să înţeleagă că există situaţii când se fac unele abateri rezonabile de la acestea. Principalul aici rezidă în faptul, ca la început părinţii, iar mai apoi copiii, să poată argumenta decizia sa despre schimbarea comportamentului şi alegerea făcută în favoarea uneia sau alteia dintre reguli. Dacă la nivelul moral, precedent, întrebarea de bază este Ce trebuie să fac în situaţia dată?, apoi, la nivelul etic, care presupune un grad mai înalt de abstractizare şi fundamentare, întrebarea care poate fi formulată de către părinţi copiilor săi este: $C e$ reguli sau principii morale trebuiesc respectate în situaţia dată? La prima vedere, întrebările par asemănătoare, însă esenţa lor diferă. În primul caz, de la copil se cere o decizie şi soluţionare concretă, iar la nivelul etic în cazul doi, pentru a răspunde la întrebare, copilul trebuie să analizeze regulile şi principiile morale care ar putea fi valorificate în situaţia dată. Aici observăm implicarea gândirii critice şi a dezvoltării capacităţilor de soluţionare a conflictelor axiologice. Totodată, aceste două nivele permit familiarizarea mai profundă a copiilor cu valorile religioase, cu esenţa eticii creştine şi spiritualizarea comportamentului [12].

\section{d) nivelul post-etic sau cel al angajamentului existenţial.}

Acest nivel discursiv valorizator în plan etic atinge profunzimea filosofică şi pune în discuţie sensul şi valoarea fiinţei umane prin conştientizarea echilibrului dintre heteronomie (lege impusă de alţii), socionomie (legea derivă din societate/standardele sociale) şi autonomie (legea impusă de sine). Noi considerăm că angajamentul existenţial în afara credinţei şi a respectării eticii creştine nu va fi unul responsabil şi valoros din punct de vedere spiritual. Finalitatea aici este libertatea, moralitatea şi spiritualitatea ca responsabilitate individuală în corelaţie cu angajamentul existenţial al omului, adică acţiunea morală materializată în conduită.

În contextul identificării fundamentelor teoretico-aplicative ale educaţiei morale se impune determinarea precondiţiilor acesteia în cadrul familiei. Problema educaţiei, la general, şi cea privind educaţia morală, în special, presupune iniţierea părinţilor într-un limbaj şi o praxiologie care i-ar ajuta să formeze şi să cultive copiii pentru ca ei să fie apţi de a-şi construi o viaţă demnă şi a fi fericiţi. 
Astfel, formarea moralităţii în cadrul familiei, noi o percepem ca pe o bază pentru orientarea spre desăvârşirea spirituală a copiilor. Formarea morală are nevoie de axarea educatorilor pe respectarea unui şir de precondiţii:

- sentimentul identităţii proprii şi a conştiinţei de sine este în centrul atenţiei părinţilor şi educaţiei familiale. Părinţii şi copiii discută şi analizează variate aspecte ale vieţii adulţilor şi ale vieţii şi conduitei copilului, concentrându-şi atenţia asupra formulării unor răspunsuri şi explicaţii la întrebarea Cine suntem? Iată, anume în acest context, ar fi adecvat să discutăm cu copiii despre religie, credință, spiritualitate;

- acceptarea de sine reprezintă următorul aspect şi criteriu important în formarea morală a copilului. El se concentrează în jurul răspunsurilor la întrebarea Ce îmi place sau ce îmi doresc?, care se cere implicată sistematic în analiza şi evaluarea conduitei adulţilor şi copiilor în cadrul familiei;

- modelul moral şi conştiinţa selectării şi urmării acestuia, vor conduce discuţiile şi comportarea în cadrul familiei spre înţelegerea importanţei exemplului pozitiv, etic al adulţilor sau a fraţilor mai mari. Modelul persoanelor apropiate este important pentru orice vârstă, însă pentru copiii de vârstă preşcolară sau şcolară mică este decisiv. În situaţia dată nu sunt satisfăcătoare explicaţiile, conversaţiile pe teme etice de tipul: Cum trebuie să mă comport sau de la cine să iau exemplu?, dar se valorifică modelele comportamentale concrete, care includ ansamblul de acţiuni şi fapte morale, respectarea eticii creştine (comunicarea, relaţionarea reală şi modalitatea de a fi a persoanei);

- activizarea la copii a conştiinţei morale prin variate moduri, căi, strategii, fie la nivelul abordării şi soluţionării unor probleme şi dileme morale, fie prin analize şi discuţii sistematice a aspectelor moral-spirituale: Cum se comportă un creştin adevărat? Care este cel mai bun lucru pentru mine? Care este cea mai valoroasă faptă în viaţa mea?, Ce înseamnă a fi spiritual? etc. (evident că sunt necesare argumentări şi comentării); 
- valorizarea conduitei morale şi a succesului acesteia reprezintă precondiţia care incumbă ansamblul de comportamente manifestate de copil pe parcursul vieţii şi maturizării sale psihofizice, morale şi sociale. Aici foarte valoroase şi eficiente sunt încurajările, îndemnurile adulţilor, aprobarea şi aprecierea faptelor copilului. La fel, necesită o atenţie deosebită discuţia şi analizele permanente a celui mai dificil, dar important aspect existenţial, concentrat în întrebarea: Cum am procedat/aç̧ionat? Evident că părinţii trebuie să cunoască esenţa educaţiei morale, a spiritualizării acesteia; să posede o atitudine şi competenţe vizavi de implicarea adecvată a copilului în toate domeniile vieţii de familie, în autoevaluarea şi estimarea fenomenelor familiale prin responsabilizarea lui, crearea situaţiilor educative şi de succes pentru a forma la copii interesul, aspiraţiile morale, deprinderile şi obişnuinţele morale.

Strategia orientării spre autoeducaţia morală, formarea şi autoperfecţionarea spirituală, orientează individul spre folosirea raţională a timpului prin intermediul aplicării unor metode, tehnici care incită la reflecţii, autoanalize, autocunoaştere, autodeterminare, evidenţiere şi cizelare a Eu-lui, reformare a unor trăsături de personalitate; formarea convingerilor, credinţei, reprezentărilor şi sentimentelor în conformitate cu standardele valorice superioare. $\mathrm{O}$ mare importanţă aici are educaţia religioasă, care ne înnobileaz $\breve{a}$ mintea şi sufletul, ne deschide spiritul către experienţe culturale diverse. Cunoaşterea valorilor religioase, spirituale, respectarea alterităţii religioase constituie un semn de moralitate şi culturalitate. Experienţa empirică şi cercetările din domeniul ştiinţelor educaţiei, demonstrează unul dintre cele mai importante momente din viaţa omului: persoana educată din punct de vedere spiritual, atinge un sens profund al vieţii şi al existenţei umane, fiind axată pe credinţă, pe acţiunea morală, responsabilitate şi iubirea aproapelui $[4 ; 5 ; 6$; $8 ; 12$ etc.]. În temeiul celor relatate, observăm că educaţia spirituală este într-o strânsă conexiune cu educaţia religioasă şi educaţia morală, deoarece ambele asigură un ansamblu de achiziţii obiectivate 
într-un şir de virtuţi personale cu conţinut determinat, în mod preponderent, prin raportarea omului la: sine, semeni, Lume, Univers, Dumnezeu, exprimându-se clar la nivel de comportament, poziţie socială, educaţie filosofică, educaţie etică, educaţie religioasă. În acest sens, considerăm oportun să ne orientăm şi spre autoeducaţie, deoarece, în esenţă, scopul unei educaţii eficiente constă în formarea abilităţilor de autoeducaţie copiilor noştri. Metodologia autoeducaţiei ca şi metodologia educaţiei morale include două modele: strategic de perspectivă şi instrumental.

În această ordine de idei, modelul strategic de perspectivă a perfecţionării morale şi spirituale, presupune aplicarea metodelor şi procedeelor raportate la obiectivele globale, care asigură formarea spiritualităţii şi a conştiinţei moral-spirituale. După cum s-a menţionat anterior, aici se îmbină metodele expozitiv-euristice (lectura; explicaţia; povestirea; conversaţia morală; dialogul moral/spiritual; dezbaterea cu caracter moral, filosofic, religios; studiul de caz; povaţa) cu rugăciunea şi metodele ce stimulează cunoaşterea de sine (reflecţia, autoanaliza, introspecţia, autoaprecierea şi autoactualizarea).

Modelul instrumental este axat pe valorificarea metodelor intuitiv-active de formare a conduitei: exerciţiul moral/spiritual; exemplul moral/spiritual; opinia publică; aprobarea; dezaprobarea; jurnalul intim; agenda personală; portofoliul autoperfecţionării morale şi spirituale.

Modelele elucidate ne orientează spre realizarea calitativă a educaţiei familiale şi a celei şcolare în scopul pregătirii copilului pentru a trece la autoeducaţie, iar funcţia centrală a autoeducaţiei rezidă în transformarea obiectului educaţiei în subiect [5]. Prin urmare, părinţii trebuie să cunoască nu numai particularităţile de vârstă şi de personalitate a copiilor, esenţa procesului educativ familial, ci şi specificul autoeducaţiei, metodele şi procedeele de formare a premiselor acesteia, etapele constituirii conştiinţei de sine şi legităţile dezvoltării spirituale şi morale a individului. În acest context vom elucida obiectivele şi metodele care pot fi aplicate de adulţi şi adolescenţi în propria formare şi autoeducaţie în corelaţie cu analiza legităţilor dezvoltării morale şi spirituale. Totodată, vom 
aborda folosirea eficientă a timpului liber, abordat ca prioritate valorică a individului, care conştientizează importanţa perfecţionării permanente, inclusiv a ireversibilităţii şi limitării timpului.

Obiectivele autoeducaţiei şi autoperfecţionării punctează traseul de orientare a individului spre optimizarea unor trăsături de personalitate sub aspect spiritual, moral, intelectual, tehnologic, estetic, psihofizic. Pentru ca procesul dat să se realizeze eficient, adulţii trebuie să ştie că autoeducaţia conştientă şi intenţionată este realizabilă în jurul vârstei de 16 ani, atunci când observăm manifestarea semnelor maturităţii şi a autonomiei morale. Faptul respectiv nu înseamnă că părinţii vor rata posibilitatea de a iniţia şi orienta copilul de 6-7 ani spre procesul de autocontrol şi autoeducaţie, familiarizare cu elementele de bază ale filosofiei practice, centrate pe acţiunea morală.

În cercetarea şi elaborarea strategiei precizate, ne-am axat pe nivelurile de evoluţie a judecăţii morale, studiate şi explicate de L. Kohlberg [11], care făcea distincţie între nivelul premoral (4-10 ani), cel al moralităţii convenţionale (10-13 ani) şi nivelul autonomiei morale (după 13 ani). Experimentul de iniţiere al părinţilor şi adolescenţilor în domeniul autoeducaţiei şi autoperfecţionării a permis să includem în tematica activităţilor nu numai aspecte teoretice despre particularităţile de personalitate şi de vârstă, ci şi legităţile, metodele dezvoltării spirituale a omului $[8, p$. 158 - 160]. Prezentăm succint conţinutul acestora, dar considerăm că pedagogii şi părinţii nu se vor opri aici, ci îşi vor aprofunda cunoştinţele în ceea ce priveşte formarea spiritualităţii. Aceste cunoştinţe, pe lângă faptul că sunt necesare şi importante oricărui individ care a decis să se orienteze spre valorizarea spiritualităţii sale şi a copiilor săi; pentru a-şi trăi viaţa onest, cu demnitate, armonios şi sănătos, sunt de asemenea foarte interesante şi utile pentru persoanele din jurul nostru, deoarece reprezintă modele de reflecţie şi acţiune filosofică şi spirituală. Cunoştinţele vizate şi strategiile perfecţionării spirituale le putem afla în literatura de specialitate cu caracter filosofic, religios, psihologic etc. Noi le vom prezenta sintetic sub forma unor legităţi-trepte, pe care trebuie să le conştientizeze şi să le urce individul în ascensiunea sa spre autodesăvârşirea spirituală şi 
morală, pentru a obţine unitatea dintre conştiinţă şi conduită; ideegând, acţiune-faptă şi comportament.

Prima treaptă în dezvoltarea şi perfecţionarea spirituală este dobândirea încrederii în sine şi iubirea, stima adevărată a aproapelui, care presupune o muncă asiduă de autoanaliză şi proiectare pozitivă a propriei persoane şi abordarea altor oameni în strânsă legătură cu conturarea scopurilor vieţii, aspiraţiilor de perspectivă, analiza personalităţii sale în conformitate cu formarea unităţii dintre minte, suflet şi corp. Acest pas îl putem lega de determinarea scopurilor individului, stabilirea poziţiei sale şi precizarea aspiraţiilor, tendinţelor, orientării spre o colaborare şi relaţionare eficientă cu alte persoane şi manifestarea iubirii pentru oameni.

Următoarea treaptă presupune formarea poziţiei de principiu: să nu te judeci pe tine însuţi şi pe alte persoane. Fiecare dată când te judeci pe tine, treci la învinuirea şi judecata altor persoane, deoarece omul nu se poate judeca timp îndelungat numai pe sine. Procesul dat poate continua la nesfârşit, el ne epuizează forţele psihice, morale şi fizice, sustrăgându-ne de la adevăratul proces de autoperfecţionare. În contextul respectiv, facem o precizare: analiza, autoanaliza, introspecţia şi alte metode de studiere a propriei persoane sau a altora nu are nimic comun cu judecata, aceasta presupunând emiterea unor idei, sentinţe cu caracter negativ şi distructiv, ce nu permit individului să se perfecţioneze spiritual.

Treapta a treia ne orientează spre aprecierea, susţinerea şi încurajarea propriei persoane şi a altor persoane prin axarea pe gândirea de tip pozitiv. Lauda, susţinerea cuiva sau autoaprobarea activizează spiritul, creează liniştea şi bucuria sufletească, făcându-1 pe om mai atent, empatic, lărgindu-i conştiinţa, pe când, judecata, aprecierea negativă, invers, o îngustează, făcândune egoişti şi invidioşi. Persoanele care lucrează asupra cizelării sale spirituale au observat că, de fapt, în viaţa şi activitatea cotidiană a omului lesne putem găsi lucruri, acţiuni, comportamente frumoase, care merită aprecierea noastră, însă noi am devenit reci, neatenţi, indiferenţi, pizmaşi, leneşi. Trăim de parcă suntem veşnici şi o să dovedim să ne corectăm, de parcă scriem viaţa pe maculator, iar mai 
târziu vom transcrie totul ce nu este bine, pe foi curate. Considerăm că am avea de câş̧tigat cu toţii, dacă ne-am învăţa să preţuim timpul, viaţa noastră, fiecare clipă şi să ne stimăm, iubim, cu adevărat, pe noi şi apropiaţii noştri.

Treapta a patra ne orientează spre a fi sinceri cu propria persoană şi cu cei din jur în faptele şi acţiunile noastre. Perfecţionarea spirituală este imposibilă în afara sincerităţii şi onestităţii. Atunci când reuşim să fim sinceri, cinstiţi ne simţim fericiţi.

Treapta a cincea ne iniţiază în respectarea legităţii spirituale care ne învaţă şi cere ca omul să fie responsabil. Calea autoprefecţionării spirituale, decizia luată de a ne autoeduca, reprezintă deja alegerea individului de a fi responsabil, ceea ce presupune acţiuni bine gândite, eficiente în relaţia cu sine, $\mathrm{cu}$ alte persoane, natura, sociumul, cu Universul şi cu Dumnezeu.

Treapta a şasea ne ajută să conştientizăm faptul: capacitatea omului de a se orienta spre viitor/perspectiva vieţii reprezintă o legitate, care ne învață să folosim posibilitățile actuale pentru a proiecta şi desfăşura acţiunile morale în timp. Să nu ne gândim permanent şi să ne concentrăm asupra evenimentelor negative din trecut, fiindcă aceasta ne sustrage de la realizările prezente şi cele de viitor, de la esenţa vieţii. Psihologii ne învaţă să ţinem minte trecutul, să facem anumite concluzii, dar să nu ne axăm pe eşecurile prin care am trecut, analizându-le la nesfầrşit, deoarece acest lucru ne macină sufletul şi forţele noastre, distorsionează autoactualizarea, ne împiedică să ne formăm şi dezvoltăm moralitatea şi sufletul.

Legitatea perfecţionării spirituale pe care urmează s-o prezentăm se află într-o strânsă legătură cu conţinutul celorlalte legităţi - trepte. Această legitate-treaptă ne orientează spre armonizarea relaţiilor intrapersonale şi a celor interpersonale; a climatului, spaţiului din jurul nostru în baza perfecţionării relaţiei om - Dumnezeu - Natură - Univers - societate. Fiecare om trebuie să se înveţe a stabili şi a întreţine relaţii decente, sănătoase, demne cu semenii săi, totodată trăind în armonie cu sine, cu preceptele eticii creştine, cu legile naturii şi ale universului, 
credinţa în Dumnezeu. În familie, dar şi în comunitate fiecare persoană trebuie să înveţe a primi realitatea adecvat, orientându-se spre conştientizarea, optimizarea, armonizarea fenomenelor existenţiale.

Desigur, cunoaşterea legităţilor-trepte ale autoperfecţionării descrise ne incită spre aprofundarea cunoştinţelor în domeniul eticii, spiritualizării educaţiei, autoperfecţionării morale şi filosofice, managementului timpului.

În scopul optimizării colaborării şcoală - familie, acordării unui ajutor concret şi calificat părinţilor în educaţia copiilor şi plecând de la aspectele aplicative ale pedagogiei şi filosofiei practice, propunem un Curriculum de educaţie a părinţilor pentru formarea competenţelor de cultivare a copiilor cu privire la orientarea lor spre autoeducaţia morală şi spirituală. Curriculumul poate fi aplicat şi completat, dezvoltat la necesitate de managerii/diriginţii şi psihologii şcolari (va fi bine dacă vom implica din domeniul teologiei).

Potrivit tendinţelor teoriei curriculare şi a concepţiei cu privire la educaţia pentru familie [7], competenţa şi eficienţa familiei vizavi de orientarea copiilor spre autoeducaţie se poate evalua şi aprecia pozitiv dacă părinţii posedă următoarele competențe:

- studiază activ şi cunosc particularităţile de vârstă şi de personalitate a copiilor, aspiraţiile şi interesele acestora;

- asigură copiilor un cadru familial moral, afectiv, spiritual, temporal şi material, de calitate;

- orientează şi determină copiii să se manifeste pozitiv şi eficient pe traseul timp şi timp liber, comportare şi fapte în conformitate cu aptitudinile, aspiraţiile morale şi necesităţile proprii şi a familiei sale;

- formulează cerinţe unice faţă de copii cu privire la autoeducaţie, autoperfecţionarea şi consumarea timpului şi pot servi drept modele demne de urmat în acest sens;

- colaborează permanent cu instituţia de învăţământ în direcţia optimizării educaţiei formale şi nonformale a copiilor pentru 
a pune în valoare autoeducaţia acestora şi consumarea eficientă a timpului şcolar şi a celui liber.

Scopul: familiarizarea părinţilor cu principiile, strategiile şi posibilităţile consumării eficiente a timpului liber şi abordării acestuia ca valoare educativă şi spirituală de autoeducaţie şi autoperfecţionare.

\section{Strategii de educaţie a părinţilor:}

Dirigintele şi psihologul şcolar implică părinţii în alegerea strategiei de desfăşurare a şedinţei. Acestea pot fi: inductive, deductive, aplicative, euristice, teoretico-aplicative, mixte.

\section{Forme de organizare/desfăşurare:}

Atelier de iniţiere şi formare; mese rotunde; traning-uri; adunări de părinţi; consultaţii individuale şi în grup; conferinţe teoretico-practice; şezători; expoziţii ale lucrărilor copiilor şi părinţilor realizate în timpul liber; întâlniri cu personalităţi marcante din diferite domenii de activitate etc.

\section{Metode:}

Lectura; explicaţia; prelegerea; studiul de caz; discuţia; reflecţia; comunicări; portofoliul familiei; exersarea; conversaţia; eseul filosofic; elaborarea proiectului personal şi al familiei de educaţie a copilului cu privire la folosirea şi dirijarea timpului liber în scopul autoeducaţiei şi autoperfecţionării.

\section{Obiective - cadru:}

- aprofundarea cunoştinţelor cu privire la valoarea moralei, a spiritualităţii omului; a educaţiei familiale în contextul formării deprinderilor pozitive de planificare-dirijare-monitorizare a timpului şi a timpului liber de către copii;

- formarea abilităţilor şi competenţelor de proiectare a vieţii familiale în onformitate cu etica creştină; cerinţele unui mod demn şi sănătos de viaţă şi a unui regim de repartizare şi utilizare eficientă a timpului.

\section{Exemple de conţinuturi:}

1. Viaţa omului, morala şi credinţa. Timpul şi timpul liber.

\section{Filosofia practică şi valorile etern-umane}


Morala şi principiile eticii creştine. Dimensiunile timpului. Viaţa omului şi consumarea timpului. Abordarea timpului ca valoare pentru a te realiza ca personalitate. Familia şi educaţia copiilor în contextul moralităţii şi spiritualităţii. Timpul liber al omului. Timpul liber în cadrul familiei şi acţiunea morală.

2. Dimensiunile timpului şi educaţia copilului. Conştiinţa morală a omului

Timpul formal / şcolar al copiilor şi timpul formal / profesional al părinţilor. Timpul informal / liber al părinţilor şi planificarea acestuia. Timpul informal / liber al copiilor. Gestionarea timpului şi educaţia copiilor în cadrul familiei. Loisir-ul şi acţiunea morală.

3. Gândirea reflexivă şi autoperfecţionarea spirituală.

Gestionarea timpului şi sănătatea omului. Conştiinţa morală a omului, autoperfecţionarea spirituală şi filosofia practică

Viaţa, gândirea reflexivă a omului, sănătatea şi timpul. Particularităţile de vârstă, regimul de viaţă şi sănătatea omului. Regimul zilei în familie şi educaţia copiilor de la naştere până la maturitate. Modelul de gestionare a timpului de către adulţi şi educaţia copiilor în familie. Sentimentele şi aspiraţiile spirituale şi morale. Viaţa, spiritualizarea educaţiei şi existenţa umană.

4. Gestionarea timpului şi formarea personalităţii copilului.

Persoana ca valoare. Moralul şi spiritualul

Educaţia moral-spirituală şi gestionarea timpului. Educaţia intelectuală şi managementul timpului. Educaţia tehnologică şi timpul omului. Educaţia estetică şi gestionarea timpului. Timpul şi educaţia psihofizică a copilului în cadrul familiei. Abordarea timpului ca valoare în educaţia familială a copilului.

5. Educaţia pentru timpul liber, autoeducaţia şi autoperfecţionarea spirituală

Educaţia prin credinţă şi formarea calităţilor moral-spirituale în contextul temporalităţii şi timpului familial, şcolar şi a celui liber. Educaţia familială, autoeducaţia şi metodele de autoperfecţionare spirituală şi morală. Odihna şi educaţia pentru timpul liber. Valorile spirituale şi morale în contextul educaţiei familiale şi a gestionării timpului. Conştiinţa şi conduita morală. 
După cum am menţionat anterior curriculumul vizat poate fi adaptat, fiind valorificat atât în educaţia elevilor (cadrul şcolar) cât şi în educaţia familiei. În cadrul experimentului realizat timp de doi ani (activitatea mea în funcţia de psiholog şcolar), prin intermediul activităţilor de consiliere axată pe dezvoltarea familiei, am obţinut o sporire a eficienţei personale a părinţilor, care a fost resimţită de copii şi cadrele didactice, care au observat schimbări calitative în comportarea elevilor. Părinţii au dorit să mai frecventeze astfel de activităţi, iar $87 \%$ de adulţi au menţionat că şi-au schimbat atitudinea faţă de educaţia copiilor săi; $53 \%$ - au conştientizat că modelul lor comportamental este decisiv în formarea morală a copiilor lor.

În concluzie, autoperfecţionarea morală şi spirituală, abordate în contextul educaţiei familiei, poate fi ajustată la orice conţinut general şi orice formă de organizare a educaţiei. Principalul aspect este reprezentat de orientarea personalităţii copilului şi a adultului spre autoeducaţie şi autoperfecţionare continuă. Noi pedagogii/educatorii să ne axăm pe ideea expusă de Im. Kant: Părinţii care au primit ei înşişi o educaţie sunt deja nişte modele după care se orientează copiii. Pentru a-i face pe copii mai buni, este necesar să facem din pedagogie un studiu; altfel nu este nimic de sperat de la dânsa, iar educaţia este încredinţată unor oameni cu pregătire rea.

\section{Bibliografie}

1. Allport, G., Structura şi dezvoltarea personalităţii, Bucureşti, Editura Didactică şi Pedagogică, 1981.

2. Andrei, Petre, Filosofia valorii. Opere sociologice, Bucureşti, Editura Academiei, 1973.

3. Antonesei, Liviu, $O$ introducere în pedagogie. Dimensiunile axiologice şi transdisciplinare ale educaţiei, Iaşi, Polirom, 2002, p. 29-53.

4. Biblia, Sfânta Scriptură a Vechiului şi Noului Testament, Minsk, Picorp, 1994.

5. Călin, Marin, Teoria şi metateoria acţiunii educative, Bucureşti, Editura Aramis, 2003. 
6. Cucoş, Constantin, Pedagogie, Iaşi, Editura Polirom, 2006.

7. Cuzneţov, Larisa, Educaţie prin optim axiologic, Chişinău, Primex-com S.R.L., 2010.

8. Cuznețov, Larisa, Filosofia practică a familiei, CEP USM, 2013.

9. Golu Petre, Psihologia socială, Bucureşti, Editura Didactică şi Pedagogică, 1974.

10. Kant, Im., Tratat de pedagogie, Iaşi, Agora, 1992, p. 14-117.

11. Kohlberg L., Dezvoltarea caracterului şi concepţiei morale la copil, în: „Psihologia procesului educaţional”, Bucureşti, Editura Didactică şi Pedagogică, 1976.

12. Opriş, M., Opriş, D., Cercetare şi religie. Repere şi demersuri comune, Cluj-Napoca, Eikon, 2013.

13. Reboul, O., La philosophie de l'éducation, Paris, P.U.F., 1976.

14. Сухомлинский, В.А., Как воспитать настоящего человека, Минск, Народная асвета, 1978.

15. Щуркова, Н.Е., Образ жизни, достойной Человека и его формирование у школьника. Смоленск, 1995. 